\title{
Between Identity Politics and Shared Identity: Re-Imaging Palestine in Selected Poems from Handal's The Lives of Rain'.
}

\author{
Yasser K. R. Aman \\ Professor of English Literature, College of Arts, Imam Abdulrahman Bin \\ Faisal University, Dammam, SA.
}

\begin{abstract}
This paper investigates Nathalie Handal's re-imaging of Palestine as the Promised Land. Such a re-imaging is crystallized through two perspectives: identity politics, which spotlights two distinctively separated groups, viz., the Palestinians and the Israelis, and shared/global identity which depends on transcendence to common humanity. Handal is a French-American poet, born in Haiti to a Palestinian family from Bethlehem. She has lived in different places in Europe, the US and Arab World. She reconstructs an image of Palestine from family memories and from her strong sense of belonging enhanced by frequent journeys to Palestine in the hope that she might have a home in poetry. In many poems such as "Ephratha", "Bethlehem", " Regrets in Galilee", "Jenin", "Gaza City", "Haifa", "Baladna" and "Amrika", Handal recalls a geomental image of home. However, a geopolitical image of home is put in juxtaposition in order to highlight Handal's journey for obtaining global identity. I argue that the two perspectives, which are intricately intertwined in Handal's poems due to her life and travels, provide a version of complete portrait of Palestine.
\end{abstract}

Keywords: Palestine, Memories, past, Identity politics, global identity, Israel, Handal, diaspora.

1 The researcher gave an oral presentation of this paper at the webinar "Heritage, Memory and Identity: Community Participation in Ecomuseums", The Architecture \& Urbanism Research Group, University of Leeds, $15^{\text {th }}$ July 2020. 
مجلة وادي النيل للاراسات والبحوث الإنسانية والاجتماعية والتربوية (مجلة علمية محكمة)

(ISSN : 2536 - 9555)

\title{
بين سياسات الهوية وإلهوية المشتركة: إعادة تصوير فلسطين في قصائد مختارة من ديوان حيوات المطر للشاعرة ناتالى حنضل
}

\author{
أ.د. ياسر خميس رجب أمان \\ أستاذ الأدب الإنجليزي- كلية الآداب لمبئ رجب المان \\ جامعة الإمام عبد الرحمن بن فيصل- الادمام - المملكة العربية السعودية الادية
}

ملخص

يناقش هذا البحث إعادة تصوير ناتالي حنضل لفلسطين كأرض الميعاد. وتتبلور إعادة التصوير في اتجاهين: الاتجاه الأول هو سياسات الهوية، والذي بدوره يلقي الضوء على مجموعتين منفصلتين هما الفلسطينيون والإسرائيليون. أما الاتجاه الثاني وهو الهوية المشتركة أو الهوية العالمية فيعتمد على الخروج من فكرة الهوية الضيقة إلى رحاب الإنسانية كهوية تضم الناس جميعاً. ناتالي حنضل شاعرة فرنسية- أمريكية ولدت في هايتي لأسرة فلسطينية من بيت لحم. عاشت ناتالي في أماكن عديدة في أوروبا وأمريكا والعالم العربي. تعيد ناتالي بناء صورة

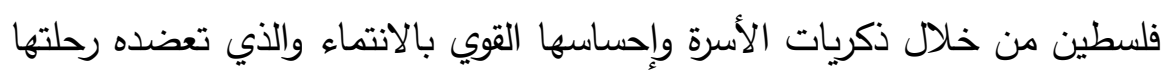
المتكررة إلى فلسطين آملةً في إيجاد موئلاً في الثعر • وتستدعى حنضل صورة جيوذهنية لمفهوم الوطن في كثير من القصائد. ومع ذلك نرى صورة جيوسياسية للوطن في مقابل الصورة الجيوذهنية، مما يسلط الضوء على رحلة حنضل نحو الحصول على هوية عالمية. ويرى الباحث أن الاتجاهين سالفا الذكر واللذان يظهرا في قصائد حنضل حالة تشابك شديد التعقيد يقدما صورة كاملة للهوية الفلسطينية كما تراها الثاعرة.

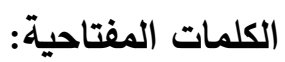
فلسطين، الذكريات، الماضي، سياسات الهوية، الهوية العالمية، إسرائيل،

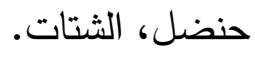


Between Identity Politics and Shared Identity: Re-Imaging Palestine in Selected Poems from Handal's The Lives of Rain.

Prof. Yasser K. R. Aman

مجلة وادي النيل للاراسات والبحوث الإنسانية والاجتماعية والتربوية (مجلة علمية محكمة)

\section{Nathalie Handal and the Palestinian-Israeli Conflict}

I am Palestinian and permanent transience has been my reality. I cannot escape the trauma of losing my 'homeland' and all that it represents for me, for the history of my people, so of course that will always transpire in my work. I live in the United States and cannot escape the experience of being held between the crack of a half opened door - on one side the view of high-rises, on the other side the view of disappearing olive trees. (Handal, "Interview with Nathalie Handal", p. 613)

Nathalie Handal is a French-American poet, playwright, producer and director born in Haiti to a Palestinian family from Bethlehem. She has lived in different places in Europe, the US and Arab World. She reconstructs an image of Palestine from family memories and from her strong sense of belonging enhanced by frequent journeys to Palestine in the hope that she might have a home in poetry. In Lives of the Rain she highlights the lives of Palestinians in exile as well as indigenous people. Handal enjoys a range of identities thanks to her travels; she is a border-crosser. Handal aspires for a global identity; therefore, in her poem "Amrika" the geopolitical dimensions of this identity have gradually been revealed with her movements from place to place. However, the geomental image of her roots has always been in the heart of her wished-for global identity:

in Haiti and in all the numerous cities we lived in, the moment I entered my family house, I entered Palestine, and more specifically Bethlehem-Jerusalem. We were surrounded by Palestinian artifacts and images, listened to Arab music, ate Arab food, spoke about the conflict, and were consumed by the scars and the elation it left 


\section{مجلة وادي النيل للاراسات والبحوث الإسانية والاجتماعية والتربوية (مجلة علمية محكمة)}

(ISSN : 2536 - 9555)

inside of us-our sense of self deeply rooted in the Holy Land, the dream of return sacred. (Handal, "“Building an Architecture for the Wanderer": A Conversation with Nathalie Handal", p. 14).

In order to explore the geomental and geopolitical images of Palestine in Handal's poems, the history of Palestine and Palestinian-Israeli Conflict is briefly discussed.

The history of Palestine has been recorded in different means of publications ${ }^{2}$. This paper focuses on the recent

2 A lot of books, articles, videos and films have recorded the history of Palestine, an Arab land. Gudrun Krämer's book A History of Palestine: From the Ottoman Conquest to the Founding of the State of Israel, published in German and translated in English by Princeton University Press in 2008, covers the period from 1750 till WWII and the establishment of Israel. Ilan Pappe's book A History of Modern Palestine: One Land, Two Peoples, published by Cambridge University Press in 2004, focuses on modern Palestine till after the period of the second Intifada. Other books, such as Preventing Palestine: A Political History from Camp David to Oslo by Seth Anziska, focus on recent periods in Arab-Israel conflict. The book, published by Princeton University Press in 2008, covers the period from Oslo to Camp David accords. A New Critical Approach to the History of Palestine: Palestine History and Heritage Project 1, edited by Ingrid Hjelm, Hamdan Taha, Ilan Pappe, Thomas L. Thompson, first published by Routledge in 2019, is the first of a series of several volumes focusing on writing "a comprehensive, evidence-based history of Palestine with a critical use of recent historical, archaeological and anthropological methods" ("Preface"). However, the editors claimed that there was no dominant ethnic group to which people living in Palestine have belonged and the account of history the book contains, twenty articles divided into four parts, might be part of the heritage of all people who live in Palestine. Many videos by Dr. Tamim Al Barghothi, a Palestinian-Egyptian political activist and poet, discussed the history of Palestine. He proved that Israel does not have any right to claim that the Palestinian lands are theirs, https://www.youtube.com/watch?v=fFFsPlmbRTs.

In this video, https://www.youtube.com/watch? $\mathrm{v}=\mathrm{CabBiViFg} 2 \mathrm{w}$, Israel occupation stealing the Palestinian legacy and showing it to the world as theirs is discussed. Moreover, Al Barghothi has written and recited many poems crystallizing the Palestinian-Israeli conflict. Of these poems are "As a Palestinian You Mustn't Live"

https://www.youtube.com/watch?v=Tz2lqTtLuEM, "In Quds" 
Between Identity Politics and Shared Identity: Re-Imaging Palestine in Selected Poems from Handal's The Lives of Rain.

Prof. Yasser K. R. Aman

مجلة وادي النيل للاراسات والبحوث الإنسانية والاجتماعية والتربوية (مجلة علمية محكمة)

history of Palestine before the declaration and the recognition of Israel in 1948 and the Palestinian-Israeli conflict. "Until 1948, Palestine typically referred to the geographic region located between the Mediterranean Sea and the Jordan River. Arab people who call this territory home are known as Palestinians. Much of this land is now considered present-day Israel" (History.com Editors). After WWI, Britain controlled Palestine and in 1947 Palestine was divided into a Jewish nation and an Arab one, with the approval of the Jews and rejection of the Arabs. In 1948 war broke out between Israel and five Arab nations: Iraq, Syria, Egypt, Jordon and Lebanon. This was the beginning of the Arab-Israeli conflict.

In 1964, the PLO was established with Yasser Arafat as Chairman till his death in 2004. In 1967, the Six-Day War broke out resulting in Israel occupying "the Gaza Strip, West Bank, Sinai Peninsula...and Golan Heights" (History.com Editors). In 1987, the first Palestinian uprising (known as Intifada) broke out resulting in Oslo Peace Accords in 1993 and 1995 according to which a Palestinian government was established and a proposal for complete withdrawal of Israeli troops from some areas was set. Israeli prime minister Ariel Sharon's visit to al-Aqsa Mosque in Jerusalem triggered the second Intifada in 2000 culminating in the Israeli army's withdrawal from Gaza. Hamas and Fatah, two Palestinian political groups, fought each other and Fatah was defeated in 2007. However, in 2014, they stroke a deal for one national Palestinian government. There have been many bloody confrontations between Hamas and Israel such as "Operation Cast Lead in December 2008, Operation Pillar of Defense in November 2012 and Operation Protective Edge in July 2014"

https://www.youtube.com/watch?v=tZTSLDVeH5M

5 
(History.com Editors). That is why Hamas was claimed to be a terrorist group.

Israeli settlements have been spreading illegally in Palestinian lands which has worsened matters. The Palestinian-Israeli conflict will not stop unless the world recognizes the pre-1947 Palestine as an Arab state, which seems to be a chimeric dream in light of the world's silent approval of all Israeli crimes committed against the Palestinians. The last stroke has been the Deal of the Century which illustrates a drastic change from geomental to geopolitical image of Palestine:

\section{The Palestinians Historic Compromise}

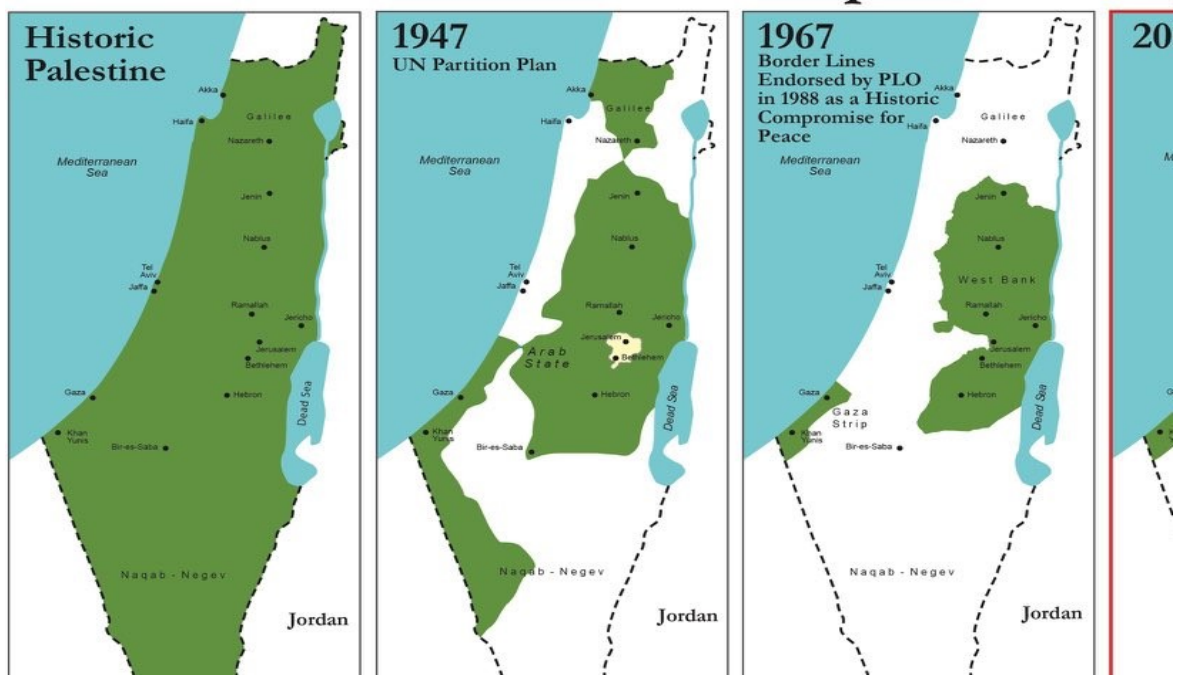

\section{Identity Politics}

In her article, "Identity Politics", Mary Bernstein traced the development of the definition of identity politics till 1990s when it came to refer to "violent ethnic conflict" and "nationalism"(48). Historical/political memory plays an important role in forming identity. Zheng Wang maintains that

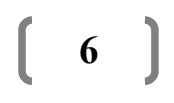


Between Identity Politics and Shared Identity: Re-Imaging Palestine in Selected Poems from Handal's The Lives of Rain.

Prof. Yasser K. R. Aman

مجلة وادي النيل للار اسات والبحوث الإنسانية والاجتماعية والتربوية (مجلة علمية محكمة)

"historical memory can serve as a constitutive, relational, and purposive content for group identity" (11).

Joshua Paul developed the concept of ant-identity identity politics as implied in "All Lives Matter" hashtag launched in opposition to that of "Black Lives Matter". He argues that: "ALM exemplifies an anti-identity identity politics (AIIP) invoking rhetoric in opposition to racial identities while smuggling in an elastic 'postracial' neoliberal subject as the foundational identity" (5).

P. G. Klandermans makes it clear that there is a strong relation between the social psychological dynamics of protest and the concept of politicized "identity". His argument focusses on how "Identity politics had bred politicized identities" (1), especially when inequalities are deliberately maintained by governments. "Arabic citizens in Israel" (1) is one of the examples he gave in order to illustrate his point. Actually, in the case of Arab-Israeli conflict, "Identity politics makes collective identities salient, contributes to their politicization and radicalization, and triggers political protest" (1). That is why world power tries to weaken social identity so that Palestinians/Arabs won't have "a shared collective identity and an increase in the strength of group identification" (3-4). The collective identity the Palestinians take is the focus of the struggle for power; that is why it is politicized.

In her article "Politics of Identity-III" Karma Nabulsi argued that her identity is not based on national characteristics that give rise to Palestinians but on "the general will" (479) of people. Nabulsi discussed the nature of the Palestinian refugees' lives pointing out that their only dream is to return home since they feel ill at ease. She maintains that: "since the original dispossession and continued displacement from their

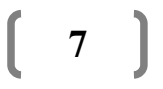


homes in 1948, the unhappy fate of the majority of Palestinians remains the core of the conflict, and is still almost entirely neglected" (481). The refugees' right to return has become a chimera. United Nations as well as Arab states failed to fulfill this dream.

The 1970s and 1980s regional conflicts resulted from both Israeli and Arab states' attempts to preclude Palestinian's political independence (483). However, and as a result of the general will of the people, in 15 November 1988, The Palestinian National Council issued the Palestinian Declaration of Independence which reached out every place and everyone in the diaspora. It is the "close link between Palestinians inside and outside the homeland" which "created a homeland in itself" (489).

In constructing Israeli national identity, it is observed that religion and politics are "deeply intertwined and constitutive of each other"; moreover, they have been "complicit in the legitimization of exclusionary politics towards the Arab population of Israel/Palestine" (Baumgart-Ochse 402).

\section{Shared/Global Identity}

Palestinians/Arabs share an identity, viz., collective identity. I see Klandermans' definition of collective identity suitable for this study. He maintains: "I use the term "collective identity" to refer to an identity shared by members of a group or category. Collective identity becomes politically relevant when people who share a specific identity take part in political action on behalf of that collective" (2). However, shared identity sometimes results in multiple identities. For example, there was a call for Palestinians and Israelis to share one identity as inhabitants of the same land. Multiple identities of Palestinians who come under such category may cause inner

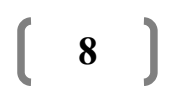


Between Identity Politics and Shared Identity: Re-Imaging Palestine in Selected Poems from Handal's The Lives of Rain.

Prof. Yasser K. R. Aman

مجلة وادي النيل للاراسات والبحوث الإنسانية والاجتماعية والتربوية (مجلة علمية محكمة)

struggle between being a Palestinian and an inhabitant of what is claimed to be Israel.

In a review of Phillip L. Hammack's Narrative and the Politics of Identity: The Cultural Psychology of Israeli and Palestinian Youth published in New York: Oxford University Press, 2011, Larry W. Chappell, commenting on Hammack's narrative theory that was applied to the US peace education program in which three groups of youth, viz., Palestinians, Israelis and Israeli-Palestinians or Palestinian-Israelis, participated, pointed out that attempts at "replacing hostile group identities with transcendent identities" (227) not only failed but resulted in "identity accentuation, suggesting increased likelihood and intensity of conflict" (227) as well.

In 2006 four documents known as the Vision Documents were published by Palestinians civil society organizations in the hope of attaining "more power sharing, recognition and equality to the Palestinian minority in Israel" (Agbaria and Mustafa 718). This of course shows how national and civic frameworks intersect and redefine each other. These documents aimed at restoring "trust in the viability and feasibility of coexistence and reconciliation between Israeli citizenship and Palestinian nationality" (Agbaria and Mustafa 719). Coexistence and reconciliation is made possible through a politics of contention and "opposing narratives to the hegemonic Zionist narrative" (Agbaria and Mustafa 726). It should be noted that "while the documents emphasize the separate rights and identity of the Palestinians in Israel, they do not call for separatism" (Agbaria and Mustafa 729). However, the introduction of "indigenousness of minorities" (Agbaria and Mustafa 730) not only differentiates between Israeli Jews and Jews coming from the diaspora but it leads to 
the " the emergence of the Palestinians in Israel as 'a third people" (Agbaria and Mustafa 730).

On the other hand, multiple identities may not result in an inward struggle so much as in a tendency for accepting the coexistence with the other. Handal's multiple identities is an example; however, "shared grievances" (11) make collective identity control over other types of identity. When it comes to Palestine's history that has deliberately been eradicated, Handal protests as a Palestinian who is keen on preserving his/her history and the image of his/her motherland. However, she aspires for a global identity and modus vivendi.

\section{Handal's Poems: Identity Politics and Global Identity: Geomental and Geopolitical images}

Because she lives in the diaspora, Handal's physical interaction with the Palestinian cause is limited per se. Elizabeth Mavroudi maintains "Palestinians are a diasporic group with a fixation on and transnational/cross-border connections to a homeland that may be more symbolic than material and whose physical involvement in homeland politics may be limited because there is no formal Palestinian state" (59).

Palestinian sacred places such as Hassan Bek mosque have always had a formative impact on the formation of national identity and politics of identity. Discussing the importance of Hassan Bek mosque, Nimrod Luz maintains that the "struggle for a particular space and the spatial changes in the socio spatial boundaries of a place are inexorably linked to politics of identity. The struggle of a subordinate group over a particular place (resistance) is by and large a spatialization of identity conflicts and, at the same time, identity constructions around a particular object" (1044). Luz aims at highlighting 
Between Identity Politics and Shared Identity: Re-Imaging Palestine in Selected Poems from Handal's The Lives of Rain.

Prof. Yasser K. R. Aman

مجلة وادي النيل للاراسات والبحوث الإنسانية والاجتماعية والتربوية (مجلة علمية محكمة)

"the political nature of the sacred and its use as a nexus of identity formation and as a site of resistance to state agencies and planning policy" (1049). This in turn redefines the politics of Palestinian identity which Luz deliberately describes it as "minor" (1050).

All selected poems are titled after cities' names, something that supports the geomental image Handal brings home through these poems. At the opening of the chapter entitled "Epistmological assessments about the Term Geomental" (Apreciaciones Epistmológicas sobre el término geomental), José Pascual Mora García gives a definition of the geomental: "The geomental term is historiographically correlated to the Annales School (1929), and is specifically correlated to the historical evolution of the concept of collective mentality, collective memory or mental tooling" (el termino geomental ... como correlato historiografico la Escuela de Annales (1929), y specificamente la evolucion historica del concepto mentalidad colective, memoria colectiva o utillaje mental) (39). In "Ephratha" Handal questions the poem and constructs an image of the city by recollecting past memories:

Poem

dressed in olive branches and cracked happiness, surrounded by seasons of sleepless nights staring at the dusty walls of cities we have lost. (Handal, The Lives of Rain 5)

The "olive branches" and "the dusty walls of cities" create a fading image summoned through memories of "sleepless nights" and "cracked happiness." Handal brings life to her memories and revives the geomental image of Ephrata by 
(ISSN : 2536 - 9555)

using poetic devices; the poem is personified into a young girl dressed in "olive branches", a very important element reminiscent of "Ephratha". In the abstract of "On Geomentality", Hong-Key Yoon maintains that :

Geomentality is an established and lasting frame (state) of mind regarding the environment. It is necessarily translated into a geographical behavioral pattern and is reflected in a pattern of cultural landscape. An individual or a group of people can hold a geomentality about a particular environment. (387)

"Ephrathah, or Ephrath, is the ancient name for the town of Bethlehem"("Ephrathah"). The very title crystallizes Handal's intention to keep connected to old names of towns, which in turn deepens the roots of Palestinians' identity.

Handal highlights loss of "address" which refers to attempts at detaching the memories from the land they memorize. Then, the idea of detachment is crystallized in an inability of remembrance of bad memories by the poem, now referring to all Palestinians, to remember: the day the soldiers marched in their villages, towns,/ houses, dreams and future, remember the crumbling of prayers/remember the gap between hands which held all (Handal, The Lives of Rain 5). The poem ends with a question that highlights the sense of estrangement: "why/ does the street have a name I can't pronounce?" (Handal, The Lives of Rain5). The question stresses rejection of geomental effacement and highlights Palestinians' identity politics. Street renaming cannot erase the history of Palestinians; rather, it makes it difficult to coexist and urges Palestinians to resist in order to preserve their identity.

From collective memory, Handal constructs a geomental image of Palestine which reflects a pattern of cultural 
Between Identity Politics and Shared Identity: Re-Imaging Palestine in Selected Poems from Handal's The Lives of Rain.

Prof. Yasser K. R. Aman

مجلة وادي النيل للاراسات والبحوث الإنسانية والاجتماعية والتربوية (مجلة علمية محكمة)

landscape portrayed in different poems in the volume under study. The Israeli attempts at reorganization of the nature of the Occupied Territories, the demolishing of Palestinians' homes and the establishment of the Settlements is an expression of the imposition of the Israeli will on the nature of the Palestinian land. Such an expression is fought back by asserting the past geomentality of Palestine by Palestinians.

Bethlehem's secrets are indecipherable and cannot be detached from the Palestinian identity as "they live in the space between our footsteps" (Handal, The Lives of Rain 9). Memories of the past are recollected as if they were a shattered sheet of glass whose arpeggio suggests an aural image crystallized in the resounding words of the grandfather and click of his beads. The vision of the past memory of Bethlehem is blurred: "I see Bethlehem, all in dust, empty/ a torn piece of newspaper lost in its narrow streets" ((Handal, The Lives of Rain 9). The present city of Bethlehem has nothing to do with the past one; so, the speakers asks "Where is the real Bethlehem...?" $\mathrm{S} /$ he gets no answer. The speaker meets people who do not remember the past and leave the speaker at a loss. "Bethlehem" starts with "secrets" and ends in "secrets", which suggests efforts exerted in order to reach a redefinition of the geopolitical identity of the place.

The meaning of international relations and geopolitics, a term coined by Rudolf Kjellén at the beginning of the twentieth century, has witnessed different changes and has been influenced by the technological advances even after the cold war so much that geopolitics has come " to include economic as well as military factors" (Deudney).The geomental reimaging of Palestine stands against a geopolitical image realized in "Bethlehem", forced by Israel and supported by international power, that aims at the effacement of 
Palestinian identity turning Palestine into a phantom sovereignty.

The title "Regrets in Galilee" illustrates a gloomy ambience of memories that hurts. The antithetical relation that exists between the two parts of the first line, "A night by a fire" and "a day in Galilee", reflects the crescendo of the tension that creeps furtively from memories recollected at that moments. Night and day represent the cycle of time, whereas fire is put in juxtaposition to the cold memories clustered around Galilee. The speaker addresses an auditor whose voice reflects a series of memories: "... all I found was a haunting/ in the middle of your speech/a bridge of echoes..." (p. 13). This aural image asserts that memories are closing in on the mind of the speaker so much that she stumbles over her dream, "like a woman wearing another woman's heels" (p.13). The simile that likens stumbling over one's dreams to wearing wrong heels/bad memories highlights the importance of detachment from a traumatized past such as "the seasons that offended $\mathrm{me} /$ and the lovers I have never unmasked..." (p.13). The speaker focuses on the present as bad memories washed off of her mind leaving an unanswered question: "What were you going to say/that night when I started travelling?/When I stopped you mid sentence?" (p.13). The closing lines raise a lot of suggestions and call for many interpretations. The question is an attempt to relate the past to the present and the unknown answer shows the influence memories can have on present and future actions. The now border-crosser might have changed her mind and stopped travelling if the other half of the unfinished sentence had convinced her.

"Jenin", as well as "Regret in Galilee", starts with the same time reference "night"; however, this time, "night" reflects the same gloomy and cold ambience of the "day in Galilee". Therefore, the cycle of time in the Occupied 
Between Identity Politics and Shared Identity: Re-Imaging Palestine in Selected Poems from Handal's The Lives of Rain.

Prof. Yasser K. R. Aman

مجلة وادي النيل للاراسات والبحوث الإنسانية والاجتماعية والتربوية (مجلة علمية محكمة)

Territories is associated with negative feelings. In "Jenin", it is a "night without a blanket" (p. 16) without a sense of warmth and belonging because the occupier stole the blanket, a symbol of safety and security. The speaker calls for coexistence, for a shared identity. The struggle for reconstructing and asserting the true Palestinian image leads to another concept, viz., the geopolitical. Under the reconstruction of geomental image of Palestine by Handal, geopiety, which refers to "a broad range of emotional bonds between people and their homeland" and topophilia which refers to "people's emotional ties with (affection for) particular places" (390) underpin the poem(s) under discussion.

She sees that blame and sadness will do no good for anyone. She believes that a new order should replace standing political struggle:

all I want is a row of olive trees, a field of tulips, to forget

the maze of intestines, the dried corners

of a soldier's mouth, all I want is for

the small black eyed child to stop wondering when the fever will stop

the noise will stop, all I want is

a loaf of bread, water

help for the stranger's torn arm,

all I want is what we have inherited

from the doves, a perfect line of white:

where are the bodies? (p.16)

"Olive trees", "tulips", "bread", "water", "help" and "doves" build an image of a peaceful country. She wonders if people can respond to her call or not. Identity struggle has 
مجلة وادي النيل للاراسات والبحوث الإنسانية والاجتماعية والتربوية (مجلة علمية محكمة)

(ISSN : 2536 - 9555)

complicated any attempt for having a shared identity because people have not had the same stance and differences among groups could not easily have been solved. However, the speaker focuses on a common element that can unify all groups, viz; humanity.

"Gaza City" illustrates an image of mortification because the city/speaker had been usurped by the occupier. This parallel image is supported with the speaker pressing her "hands and "check" [sic] "against the wall", a synecdochical reference to the city, hiding "like a slut, ashamed" (p.19). The speaker identifies with the city so much that her body reflects the resistance against changing the geomental image of the city:

I pull the collar of my light blue robe so hard it tears, one side hanging as everyone's lives hang here.

My fingers sink deep into my flesh, I scratch myself, three lines scar my breasts, Three faiths bound in my head and I wonder If God is buried in the rubble. (p. 19)

Gaza is torn between the Jewish occupier and Christian and Muslim Palestinians. This trilogy of religion is symbolized in the three scars of the speaker's/the city's breasts. The three religions cannot provide a solution; so, the speaker doubts the existence of Justice, of God. Therefore, houses are considered prisons and rooms dog cages.

The speaker portrays an image of present Gaza that is opposite to the past one. There is no "Debke", a symbol of happiness and weddings, but there are funerals instead. The

${ }^{3}$ Debke was originally used while Palestinians were harvesting their crops. Then it was used in weddings as an expression of joy in pre- 1948 Palestine. After 1948, it was used as an expression of Palestinian identity, protest and struggle against the occupier (https://www.youtube.com/watch?v=whc5GPEt4Do). 
Between Identity Politics and Shared Identity: Re-Imaging Palestine in Selected Poems from Handal's The Lives of Rain.

Prof. Yasser K. R. Aman

مجلة وادي النيل للاراسات والبحوث الإنسانية والاجتماعية والتربوية (مجلة علمية محكمة)

metaphor of Gaza likened to a woman laboring to give birth without receiving any help is an indirect indictment of Arab nations who have given a blind eye to what has been happening in Palestine. The image is of the past Gaza with its streets, hospitals, schools, airport had vanished long ago.

Even the atmosphere is deadening so much so the speaker is "chocking on my spit" (p. 19). Although people have resisted attempts of destroying the geomental image of Palestine, the face of the city has gradually changed.

"Haifa, Haifa" records a bitter experience of leaving Palestine and moving into diaspora. Memories complete the gloomy atmosphere in the above poems: broken walls/dusty roads/nightmares" (p. 23). The image of a destroyed city illustrates attempts at obliterating the geomental image of Palestine and Palestinian identity. It results into psychological disturbances crystallized in "nightmares". This trauma has accompanied Palestinians in the diaspora where they have been waiting to "live the way we should live..." (p. 23). Enjoying life is a perpetual retrieval. It depends on going back home. Handal once stated:

I feel free only in Palestine because it is only there that I am whole, that I see Nathalie and understand who she is. It is only in Palestine that I can hear my heart beating as I look at a butterfly on the windowsill and understand what flight means ...understand that love can only exist if we allow hearts true freedom. ("Interview with Nathalie Handal", p.615)

However, attempts at effacement of Palestinian identity have not stopped: "The lemon trees keep disappearing/ and the weather keeps changing/we keep aging" (p. 23). Each time a Palestinian visits Palestine, they find more Palestinians 
(ISSN : 2536 - 9555)

leaving. The poem highlights the impossibility of regaining the past image of Palestine, an unoccupied independent country.

The title "Baladna", an Arabic word, can mean "our country" or "our ballad". The first meaning is suggested by the opening lines and the second one closes the poem. The pun brings into mind an image of a myriad of memories of homeland. These memories can be commemorated in a ballad.

Between reality illustrated in "we are who we are" and past memories remembered in "the common things" stands the speaker whose identity is torn between the past and the present:

We are who we are, and home is home

to keep the season dreaming

to remind us of

ahweh, zaatar, khoubiz, kaak-

the common things

I am no longer sure what I see. (p.33)

Through her geomentality speaker recalls past daily activities in the hope that she might regain her lost identity. "ahweh, zaatar, khoubiz, kaak" are cultural specific activities that distinguish Arab identity.

Geomentality is the mentality of an individual or a group of people (whether cultural, professional, or racial) regarding the geographical environment. Geomentality can therefore include any pattern (established set) of mind about places and environmental conditions including people's place preferences and prejudices. ... it 
Between Identity Politics and Shared Identity: Re-Imaging Palestine in Selected Poems from Handal's The Lives of Rain.

Prof. Yasser K. R. Aman

مجلة وادي النيل للار اسات والبحوث الإنسانية والاجتماعية والتربوية (مجلة علمية محكمة)

is an integral part of individual or group mentality as a whole (Yoon 388)

The speaker's attempt fails at keep a geomental image and she is "no longer sure what [she] see[s]". Visions are so blurred that she cannot distinguish "a herd of sheep" from "a burning mountain" (p. 33). Moreover, the speaker starts self-effacing her past identity by feeling indifferent to her stance "between [her] grandfather/and what seems to be [her] present" (p.33). Many factors have made the speaker lose interest in her past, the important of which is moving into the diaspora. Another concept of identity, viz., transnational identity, has gradually been formed. Her doubt of being different from her ancestors culminates into "we are who we are; are we who we are?" (p.33).

Being influenced by diasporic ambience and the newly attained identity, the speaker's memories of her past have dwindled into a doubtful ballad: "We write a ballad to celebrate ourselves, baladna/and wonder, is that what it's like/to dance in Arabic..." (p.33). All past memories and activities which have long constructed her identity have been reduced into a ballad fit for performing an Arab dance. However, the closing lines bear a sense of mortification that should be felt by all Palestinians living in the diaspora. They should all past memories of old Palestine in order to cling to their Palestinian identity.

"Amrika", the longest poem in Lives of Rain, crystallizes the transnational identity the speaker has acquired while moving from place to another in the diaspora. The poem provides intersecting cultural webs, a tapestry, a patchwork, delicate in its composition as well as in its expression. "Amerika" turns all concepts of the only and one identity 
topsy-turvy. Through this multilingual poem Handal realizes her global identity. It is language that can gather, accommodate and recreate. Handal maintains that: "no language is untouched, they all carry the remains of other civilizations and conquests. And it's in these connections that I am reminded of our global gathering. Exile is an unsolvable grief. But with language my hyphenated mother tongues have found a way to create an original language" (Handal, "Diasporic Cartographies", p. 143). For Handal the many hyphenated languages she speaks have almost become synonym to identity: 'I've often said I don't have a mother tongue. In fact, they are all hyphenated mother tongues. Together they create a symphony, a new language, and the multiplicity of that new language reflects my identity and life" (Handal, "Building an Architecture for the Wanderer" p.13).

This eight-part poem takes one in a multi-leg odyssey, breathless yet enlightening. From "The Curfews of History", to "The Tyranny of Distance", "The Cry of Flesh", "Opening", "El Color del Inmigrante", "Another Sun", "Incantations", till one reaches the last part "Debke in New York", one acquires a kaleidoscopic and psychedelic vision of the speaker's identity, one that combines memories of home- "Debke"- and the present status- "New York"- so much that the speaker, while moving on and gaining experience, sticks to their roots. Handal makes it clear that her identity is like a multi-facet gem created by her constant travels: "My life is a series of residencies in the skies. I don't know how to live differently, and don't think I want to, either. My home is in flight" ("Building an Architecture for the Wanderer": A Conversation with Nathalie Handal", p.17).

In the first part, the speaker spends "nights all night digging" (p.57) for parts/memories of her "Sittis and Jiddos" (grandmothers and grandfathers). The physical act of digging 
Between Identity Politics and Shared Identity: Re-Imaging Palestine in Selected Poems from Handal's The Lives of Rain.

Prof. Yasser K. R. Aman

مجلة وادي النيل للاراسات والبحوث الإنسانية والاجتماعية و التربوية (مجلة علمية محكمة)

for an "arm, leg, finger, a silver of hair" (p.57) suggests another spiritual counterpart making the synecdochical reference cover not only "Sittis and Jiddos" but all past memories as well. Memories haunt the speaker and her kinsmen while "walking to all borders" (p.57), memories such as "the bruised child, the throat of our national song" (p.57). Sticking to memories were a strong support against the image of the now "divided country" (p.57).

Memories, customs and traditions have been transmitted from generation to another by telling tales about the past:

women weave, weave

thread after thread,

lost songs of Palestine, Oum Kulthoum

buildings built and torn down,

the way home changing as the city does-

with every bomb, a new wall. (57-58)

The above lines reflect the long-standing struggle between the geopolitical image crystallized in daily bombings and new walls being built and the geomental one created by serious attempts and reviving the past image of Palestine. The speaker sees that revival of past traditions is the best way to stand against daily attempts at eradicating the image of old Palestine: "we continue to dance, hands swaying/the air $Y a$ Allah, Ya Allah,/we will never leave" (p. 58). It is important to note that the poem starts with the word "distance" and ends with "never leave", an indication that a second coming is always at hand.

In the second part a comparison is held between two cities: Marseilles and Jaffa, "between the city of lights and blackouts" (p.58). Moving to France does not efface their identity since "our eyes remain, our memory" (p.58). The speaker's 
actions are imbued with a strong sense of her Palestinian identity in the new residence Memories of home haunt the present so much that she sings Arab songs in French, and revives an old love story that entails questions about the possibility of returning to the promised land: "Will we ever smell the sweet scent of morning/in Haifa again" (p.59). The closing lines of her letter to her lover answers this question: "Je n'ai jamais oublie/ce que tu n'as pas cesse de me dire,/la terre ne ment jamais" (p. 59).

Part three reflects the vicissitudes of life in the Diaspora. References to "Antilles", "the island of Boukman", "Tabou Combo and Sweet Mickey" (p. 59) shift the scene from France to "Ayiti cherei, plus bel pays-" (p. 60). Spatial and cultural references help crystallize the speaker's transnational identity. She has mingled with different people and things: "I leave with the Kreyol-/tioul, zonbi, refijye, testaman" (p.60). The speaker has acquired experience and can live in the Diaspora convinced that "we did what we had to,/but it was not enough" (p.60). There are more places in order for her new identity to be fully constructed.

Part four opens with a new spatial reference, "New England". This marks the crescendo of the transnational identity. There is a marked difference "between where we are from and/where we now live in" (p.60). Hopes and dreams can be fulfilled in the new residence, something difficult to realize in the homeland that is now a pack of memories trapped "behind a broken door" (p.60). Memories of the old identity flash over the scene since "only later do I hear the Arabic/ in his [her father's] footsteps..." (60). Although "New England" is in the foreground of the scene with a clear reference to the American dream since time "wears a hat and own a car/and we are comfortable in foreign tongues" (p.61), the only music that can stir emotions "is a melody from the 
Between Identity Politics and Shared Identity: Re-Imaging Palestine in Selected Poems from Handal's The Lives of Rain.

Prof. Yasser K. R. Aman

مجلة وادي النيل للاراسات والبحوث الإنسانية والاجتماعية والتربوية (مجلة علمية محكمة)

east-" (p.61). The implication is that though a stranger can achieve acculturation, atavistic feelings will always lurk in the deep reaches of their soul.

Part five shifts the scene to Cuba where the speaker and her company "reach the Miami beat" and an aural image is crystallized by a cultural reference to the well-known Cuban singer Celia Cruz's "la tierra de Dios" (p. 61) (the land of God). The speaker is convinced that she should be on the move in order to realize her full transnational identity: "leaving, we survive" (p.61).

The title of part six is a temporal and spatial reference to the speaker's constant movement. The speaker and her company reach the sweet island, "Santo Domingo" and "listen to Bachata, Juan Luís Guerra,/speak about Sosa, El Camino Real/ las calles en la Zona Colonial" (p. 62). Handal highlights ties between Palestine and Latin America to which many Palestinians immigrated. "the imaginative intertwinings of Bethlehem, Haiti and the Dominican Republic are explored in the poetry of Palestinian US-based poet Nathalie Handal" (Abdel Nasser p. 240). References to cultural practices, famous figures and historic places highlight the intensity of the experience the speaker has gained. Cultural references color the rest of the poem. References to priests, witches, buildings, towers, slums, ghettos, suburbs create an image of another place different from her own home land. Another psychedelic image is illustrated by drinking mamajuana. The trilogy of time intersects so much so the speaker is confused:

Why do we insist

on disappointing ourselves-

past or future

suspense or dream

instead of hoping the present. (pp.62-63)

23 
The above lines show that memories filter through the interstices of her new transnational identity. Attempts at acculturation in different places the speaker has visited cannot prevent memories from haunting her present and future.

In part seven the scene is London where nature and literature create an enigmatic ambience. She had memories of "Shakespeare", "Yeats" and "Beckett" while "smoking sheesha on Edgeware Road" (p. 63). Sheesha-created mist and Portobello Market's odd colors intensify this sense of enigma. The psychedelic vision the speaker has had before, runs in this part since she sees mist as a room where she can disappear in. Although the new and old identities show their appearance simultaneously, the speaker tries to incarnate the new one:

where I came to know

the silent rain inside of me

as the Thames has come

to the rhythm of my breathing. (p. 63)

The aural image created by murmuring of the Thames and the speaker's breathing highlights the extent of the speaker's inculturation.

Handal's reading of "Shakespeare", "Yeats" and "Beckett" highlights the importance of geopolitics. As mapping's underpinning relation to geopolitics has often affected people's life, the latter opens a new door for reading literature which has been depoliticized for a long time. An example is Fionnuala O'Neill's and Stuart Elden's reading of King Lear which reads King Lear as a historical and political record rather than a tragedy. O'Neill maintains that:

One of the most productive aspects of Professor Elden's reading, then, lies in its capacity for putting Lear into dialogue with the histories and some of their most pressing concerns regarding absolute sovereignty and the 
Between Identity Politics and Shared Identity: Re-Imaging Palestine in Selected Poems from Handal's The Lives of Rain.

Prof. Yasser K. R. Aman

مجلة وادي النيل للاراسات والبحوث الإنسانية والاجتماعية والتربوية (مجلة علمية محكمة)

commonwealth, including the relationship between the monarch, the territories, and the commons. Reading these plays both within and against generic frameworks thus draws attention to the shatteringly tragic potential

of territorial dispute on a national scale, as well as to the political nature of tragedy. (168)

Selden focuses on the term "territory" in its relation to geopolitics (148). For Elden "territories" has to do with "political control of and stake in those place" (148), viz., France as reported by Lord Somerset in Henry VI, Part II. The same reference to "territories" is found in King Lear. The word "implies a range of political issues: it is controlled, fought over, distributed, divided, gifted, and bought and sold" (160).

Mireya Folch-Serra pointed out that the concept of "the nation-state" was based on the ideas of "national identity" and "manufactured unity" (177) within national borders. Through her analysis of the Spanish translation of Tom Clancy's OpCenter: Balance of Power, she discovered that the translation is different from the original because the "Spanish version sought to sanitize so-called inexact geographical and historical facts, and supposedly bring the text closer to "reality"" (178), thus emphasizing how media and censorship can affect the geopolitics of identity.

The title of part eight, "Debke in New York"-the last part in this poem-has cultural and spatial references to the old and new identities respectively. The hustle and bustle of New York is put in juxtaposition to her homeland since the speaker says: "the past a bedroom I once slept in" (p.64). References to places she goes to- "Broadway", "Columba", "Hudson River", "subway rides", "that place I now call home", and "the 
corner of Bleeker and Mercer" (p.64)- illustrate social mobility. However, references to cultural figures, writers and singers from both sides- "Said and Twain", "Ibn Arabi" and "Abdel Halim and Nina Simone"- show that the two identities are intermingled and transformed into one, viz., global identity.

Handal's cultural references is an attempt at mapping the new identity so much that Palestinians/people in the diaspora can embrace it. In his article "Editing worlds: participatory mapping and a minor geopolitics", Joe Gerlach points out the role mapping plays in considering geopolitics from a new angle by maintaining that mapping is geopolitical not only for "its implication in the practices of statecraft and of delineating sovereignty in a 'major' representational sense" but also for reshaping "attitudes", "dispositions" and "sensibilities" in a particular way (274).

Handal's references suggest remapping and revisioning old masters such as Ibn Arabi, Said and Mahmoud Darwish. Alan Ingram argues that research in the "(geo)political implications of art" can be developed through an "appreciation of the aesthetics" (2). The same can be said about Handal's poetry in which geopolitics plays a formative role.

The lesson the speaker tries to teach the world is clear. She "wonder[s] why we are obsessed/ with difference,/our need to change the other?" (p. 64). These lines reflect the speaker's belief in the image of the melting pot, a belief that there is diversity within unity and this diversity should be respected. Issues of Displacement and identity are not easy to deal with. Handal sees that "if we think we can achieve resolve with the question of displacement and identity, we will feel defeated. The aim is to maintain equipoise as if we were playing a dangerous sport" (Handal, "Diasporic Cartographies", p. 144). 
Between Identity Politics and Shared Identity: Re-Imaging Palestine in Selected Poems from Handal's The Lives of Rain.

Prof. Yasser K. R. Aman

مجلة وادي النيل للاراسات والبحوث الإنسانية والاجتماعية والتربوية (مجلة علمية محكمة)

The odyssey is complete and "faded Arabic letters" and "a New York debke" (p. 64) close this multicultural scene. What Handal has done is that she has "synthesize[d] the culture and memory repertoires which she has interiorized" (El Hajj and Harb p. 82). The last lines stress the fact that identity search is a never-ending process: "my voice still breaking into tiny pieces/ when I introduce myself to someone new/and imagine I have found my way home" (p. 64). The aural image points to the difficulty in breaking ice with strangers. The speaker tries to socialize, acculturate and build an identity and find "home". Discussing Nathalie Handal and Naomi Shihab Nye, Hind El Hajj and Sirene Harb maintain that: "through travel and political comparativity, the articulation of personal and collective identities becomes a never-ending journey and an act of resistance against racism, colonial regimes, and imperial and interstate violence" (pp.62-63).

\section{Conclusion}

Re-imaging Palestine in selected poems of The Lives of Rain has been realized through two perspectives, viz., identity politics and shared/global identity which are related to the geomental and geopolitical images of Palestine respectively. Discussion of the above-mentioned poems have proved that Handal has succeeded in having a home in poetry. Handal realizes that she has to live with the idea of loss of home and permanent transience. Her poems prove that memories of home are deeply rooted in her despite the fact that she has lived in different places. A brief discussion of PalestinianIsraeli Conflict shows how identity politics has been a result of this struggle and justifies Handal's aspiration for global identity and modus vivendi. Handal's cultural references have opened new venues to remapping literature and revisioning 


\section{مجلة وادي النيل للاراسات والبحوث الإنسانية والاجتماعية والتربوية (مجلة علمية محكمة)}

(ISSN : 2536 - 9555)

old masters' works from a politicized perspective in order for the geomental image of Palestine to be kept for future generations. The above discussions have proved that writing poetry creates, recalls and preserves memories so that one's ethnic identity may be kept under a wider global one.

\section{Works Cited}

Abdel Nasser, Tahia "Palestine and Latin America: Lina Meruane's Volverse Palestina and Nathalie Handal's La Estrella Invisible", Journal of Postcolonial Writing, 54:2, (2018) 239-253, DOI: $10.1080 / 17449855.2017 .1325771$

Agbaria Ayman K. \& Muhanad Mustafa. "Two states for three peoples: the 'Palestinian-Israeli' in the Future Vision Documents of the Palestinians in Israel", Ethnic and Racial Studies, 35:4, (2012):718-736, DOI: $10.1080 / 01419870.2011 .598234$

Baumgart-Ochse, Claudia. "Opposed or Intertwined? Religious and Secular Conceptions of National Identity in Israel and the Israeli-Palestinian Conflict", Politics, Religion \& Ideology, 2014 Vol. 15, No. 3, 401-420, http://dx.doi.org/10.1080/21567689.2014.948531

Bernstein, Mary. "Identity Politics", Annual Review of Sociology, vol. 31, 2005, pp. 47-74. ProQuest,

https://library.iau.edu.sa/docview/199616081?accountid=136546, doi: http://dx.doi.org.library.iau.edu.sa/10.1146/annurev.soc.29.10202.100054

Chappell, Larry W. (2012) Review of Narrative and the Politics of Identity: The Cultural Psychology of Israeli and Palestinian Youth, Journal of Political Science Education, 8:2, 226- 227, DOI: 10.1080/15512169.2012.667663

Deudney, Daniel H. "Geopolitics", Encyclopcedia Britannica, Encyclopædia Britannica, inc., June 12, 2013,

https://www.britannica.com/topic/geopolitics, accessed in December 17, 2019.

Elden, Stuart. "The Geopolitics of King Lear: Territory, Land, Earth", Law \& Literature, (2013) 25:2, 147-165.

https://doi.org/10.1525/lal.2013.25.2.147

El Hajj, Hind and Sirene Harb. "Travel, Relationality and Privilege in Palestinian American Poetry", Mashriq \& Mahjar 3, no. 2 (2016),6287. 
Between Identity Politics and Shared Identity: Re-Imaging Palestine in Selected Poems from Handal's The Lives of Rain.

Prof. Yasser K. R. Aman

$$
\text { مجلة وادي النيل للاراسات والبحوث الإنسانية والاجتماعية والتربوية (مجلة علمية محكمة) }
$$

"Ephrathah". aboutbiblioprophecy.com.

http://www.aboutbibleprophecy.com/s72.htm . 24 April,2020

Folch-Serra, Mireya. "The Geopolitics of Identity: Popular Literature, Censorship, and the Spanish Media", Identity: An International Journal of theory and Research, 2:2, 177-193, DOI: 10.1207/S1532706XID0202_05

García, José Pascual Mora. La Dama, el Cura y el Maestro en el Siglo XIX (The Lady, the Cure and the Master in the 19th Century), Mérida: Universidad de Los Andes Consejo de Publicaciones, 2004.

Gerlach, Joe. "Editing worlds: participatory mapping and a minor geopolitics", Transactions, The Institute of British Geographies, doi: $10.1111 / \operatorname{tran} .12075$.

Gordon, Nahida. Palestine Is Our Home: Voices of Loss, Courage, and Steadfastness. Amazon Digital Services LLC - Kdp Print Us, 2016.

Handal, Nathalie. The Lives of Rain. Northampton: Interlink Books, 2005.

---. "Diasporic Cartographies: An Interview With Nathalie Handal" by Lily Pearl Balloffet \& Elizabeth Claire Saylor. Mashriq \& Mahjar 4, no. 1 (2017), 141-146.

--- . "Building an Architecture for the Wanderer": A Conversation with Nathalie Handal", by Rachel Morgenstern-Clarren. World Literature Today (2016), 12-17.

https://www.worldliteraturetoday.org/2016/may/building-architecturewanderer- conversation-nathalie-handal-rachel-morgenstern-clarren Accessed 6 July, 2020.

---. "Interview with Nathalie Handal", by Lisa Suhair Majaj, International Feminist Journal of Politics, 8:4, (2006) 612-617, DOI: $10.1080 / 14616740600980336$

Heyes, Cressida. "Identity Politics.” Stanford Encyclopedia of Philosophy. 23 May, 2016.

https://plato.stanford.edu/entries/identity-politics/\#Bib . Accessed 7 Nov., 2019.

History.comEditors."Palestine".21Oct.2019.

https://www.history.com/topics/middle-east/palestine\#section 11.

Accessed on 27 Nov. 2019. 


\section{مجلة وادي النيل للاراسات و البحوث الإنسانية والاجتماعية والتربوية (مجلة علمية محكمة) \\ (ISSN : 2536 - 9555)}

Ingram, Alan. "Rethinking art and geopolitics through aesthetics: artist responses to the Iraq war", Transactions, The Institute of British Geography, 201641 1-13 doi: 10.1111/tran.12099.

Klandermans, P. G. "Identity Politics and Politicized Identities: Identity Processes and the Dynamics of Protest", Political Psychology, Vol. 35, No. 1, 2014. Doi: 10.1111/pops.12167

Krämer, Gudrun. A History of Palestine: From the Ottoman Conquest to the Founding of the State of Israel. Princeton: Princeton University Press, 2011.

Luz, Nimrod. "The politics of sacred places: Palestinian identity, collective memory, and resistance in the Hassan Bek mosque conflict", Environment and Planning D: Society and Space 2008, volume 26, pages 1036-1052, doi: $10.1068 / \mathrm{d} 2508$.

Maguire, Laura. "Identity Politics." Philosophy Talk. 14 July, 2016. https://www.philosophytalk.org/blog/identity-politics. Accessed 7 Nov., 2019.

Mavroudi, Elizabeth. "Palestinians in diaspora, empowerment and informal political space”, Political Geography 27 (2008) 57-73.

doi:10.1016/j.polgeo.2007.06.009

Nabulsi, Karma. "Politics of Identity-III", Government and Opposition, Cambridge University Press, Vol. 38, No. 4 (AUTUMN 2003), pp. 479496.

O’Neill, Fionnuala. "Toward Tyranny: Geopolitics and Genre, A Response to Stuart Elden, Law \& Literature", (2013) 25:2, 166-174.

https://doi.org/10.1525/lal.2013.25.2.166

Pau,1 Joshua. "'Not Black and White, but Black and Red': Anti-identity identity politics and AllLivesMatter", Ethnicities 2019, Vol. 19(1) 3-19.

DOI: $10.1177 / 1468796818791661$

The History of Palestine. https://www.youtube.com/watch?v=n3bxj1uvDXU. mingoi313. Youtube. 30 May 2009. Accessed 16 Nov. 2019.

Yoon, HK. GeoJournal 1991 (Dec) by Kluwer Academic Publishers (1991) 25.4: 387-392. https://doi.org/10.1007/BF02439490.

Wang, Zheng. Memory Politics, Identity and Conflict, Memory Politics and Transitional Justice, 2018.

https://doi.org/10.1007/978-3-319-62621-5_1 